Anat. Labor. of Prof. H. SETO, Tohoku University, Sendai.

\title{
On the Sensory Innervation of Pars Diaphragmatica Urethrae of Bat.
}

蝙蝠尿道横隔膜部の知覚神経分布飞就いて,

Toru NUMATA, Shosuke NIIZUMA, Kazuo NOZAKI and Makoto KOMATSU

沼田透, 新妻正助, 野崎一男と小松誠.

[Received October 22, 1955.]

At this laboratory, SETO's discovery of many interesting sensory terminations in the mucous membrane of the pars cavernosa urethrae in man, in 1939, was followed by NOBU'TA's equally interesting report on various sensory terminations in the pars prostatica urethrae in man (1948) and by the interesting results of the histological studies on the sensory terminations in the pars cavernosa urethrae in the topmost part of pig penis by ENDO (1945) and on those in the pars pelvina urethrae in cat by MORI (1955).

In succession of these illustrious forerunners, the authors of this paper have been granted the opportunity to study the innervation, especially, the sensory innervation of the pars diaphragmatica urethrae in bat, a subject on which no one has ever reported. The preparations used in our study were the same as used by NIIZUMA, one of the authors, in his study on the innervation of the rectum and the anus of bat, consisting of a large series of transverse sections very beautifully stained with SETO's silver impregnation as usually practiced at tnis laboratory and including transverse sections of the urethra as well as of the rectum and anus. Subjecting these sections to minute microscopic examination, and comparing the findings with those reported by the above mentioned predecessors on human and animal urethrae, we have succeeded in arriving at the results detailed in the following.

\section{Indivdual Views.}

As shown in Fig. 1, the pars diaphragmatica urethrae in bat is formed in transverse sections in a meniscus extending bilaterally and convex ventralwards, and on the dorsal side of the urethra, COWPER's glands are found in powerful development, partly reaching the ventral side of urethra in existence. On both sides of the COWPER's glands a re found well developed longitudinally running striated muscle layers, a part of which pass over into a striated muscle layer running circularly on the 


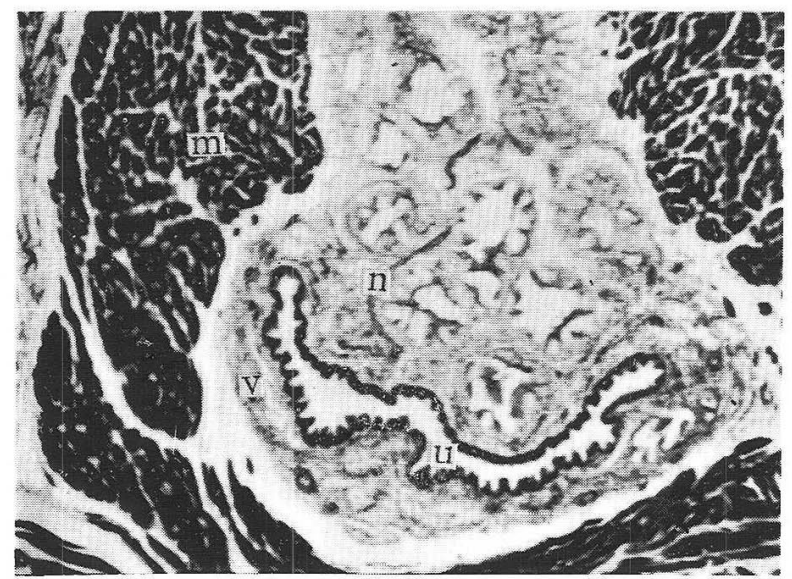

Fig. 1. Pars diaphragmatica urethrae of a bat in a transverse section. $u$ urethra showing many small longitudinal mucous folds; $n$ nerve bundles running through the COWPER's glands; $m$ longitudinal striated muscle layer; $v$ venous plexus. SETO's impregnation. Photo $\times 30$.

ventral side of the urethra.

The mucous membrane of the urethra, except at the median part of the dorsal side, forms many small longitudinal folds arranged rather regularly. It is covered by a 2 or 3-rowed cylinder epithelium, and its comparatively narrow propria is composed of fibrous connective tissue containing a relatively large number of blood capillaries. On the ventral side of the urethra, frequent existence of venous plexus touching the ontside of the propria is seen.

The nerves supplied to the pars diaphragmatica urethrae of bat, as illustrated in Fig. 1, run through the interlobular connective tissue of the COWPER's glands to come out in the propria of the urethra. These nerve bundles consist of a small number of fine vegetative fibres and a large number of myelinated sensory fibres. They come into ramification in the propria to form rather poor plexus, and the sensory fibres in thom diffuse out subepithelially, in most cases ending in the propria, but in some cases running further into the epithelium.

Thus, the develepment of the sensory fibres here is rather good, but in comparison with that of the sensory fibres in the pars pelvina urethrae in cat (MORI), we must admit it is much poorer, for we find not only a much smaller number of sensory fibres themselves, but also nothing but far simpler formed terminations of them in bat. Many small-sized genital nerve bodies and PACINIan bodies have been found in the propria mucosae of the feline pars pelvina urethrae by MORI, but in the pars 
diaphragmatica urethrae of bat, no such corpuscular endings nor any terminations comparable with these have been demonstrated at all. Their development may be said to be poorer than in human urethra (SETO, NOBUTA) too.

The sensory terminations found in the pars diaphragmatica urethrae of bat are mostly in the forms of unbranched and simple branched terminations, and some of the sensory fibres run further into the epithelium to pass over into intraepithelial fibres. But these intraepithelial fibres never end in such very complex branched terminations as found sometimes in man and cat, always ending in short unbranched endings in bat. Their number is never called to bo large.

You see that the sensory fibres illustrated in Fig. 2 are mostly ended in unbranched and simple branched terminations in the propria. In most cases, tho terminal fibres gradually taper off into sharp points. The intraepithelial fibres too are found to end sharply soon upon entering the epithelium without branching out.

Fig. 3 shows a simple branched termination consisting of 3 branches terminating closely beneath tho opitholium and an unbranched termination. In these terminations, a rather marked winding is seen in the courses of their branches. Many of the terminal branches in the sensory terminations formed in the mucous

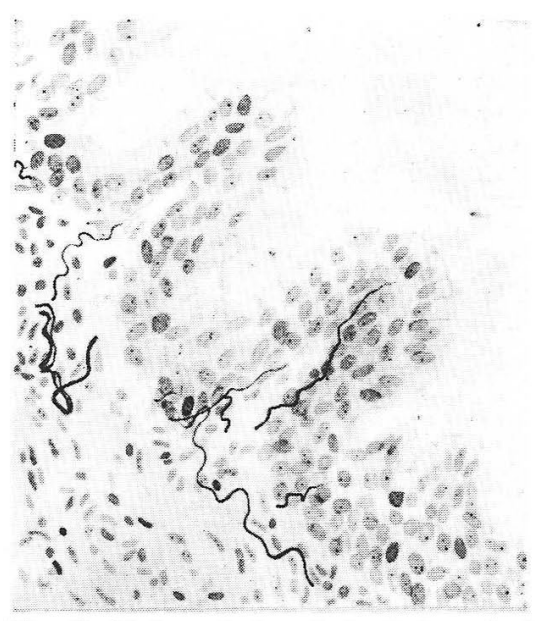

Fig. 2. Unbranched and simple branched sensory terminations in the propria and 2 unbranched sensory fibres in the epithelium. Pars diaphragmatica urethrae of a bat. Same staining. $\times 500$, reduced to $2 / 3$. membrane of the bat urethra show such a strong undulation. Almost all such terminal fibres end sharply.

That sensory terminations are formed around gland ducts has been reported in many studies conducted at this laboratory. For cxample, sensory fibres are found very frequently penetrating into the epithelium of the ducts of the mucous glands of the palatum molle, to form powerful intraepithelial fibres (SAKAI). SETO has found complex branched terminations formed by rather stout sensory fibres around the ducts of the human urethral glands, and that their terminal branches often develop into intraepithelial fibres. We also have found along the ducts of the 


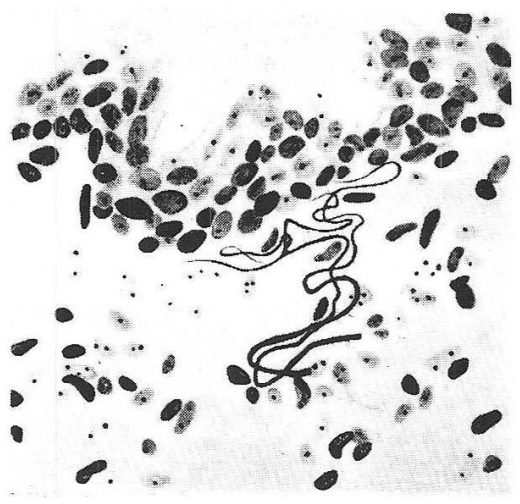

Fig. 3. A simple branched and an unbranched sensory terminations running strong winding courses formed subepithelially. Pars diaphragmatica urethrae of a bat. Same staining. $\times 500$, reduced to $2 / 3$.
COWPER's glands in the pars diaphragmatica urethrae in bat sensory fibres, some among them very thick, running always singly close to the outside of the epithelium of the ducts, showing more or less winding in their courses, and only rarely branehing out into $2-3$ branches, but, mostly unbranched, ending in blunt or sharp points. In some rare cases, these fibres form intraepithelial fibres, but usually, they end extraepithelially.

In Fig. 4, a bifurcated sensory termination of a thick fibre formed around a gland duct is shown, while in Fig. 5, we see

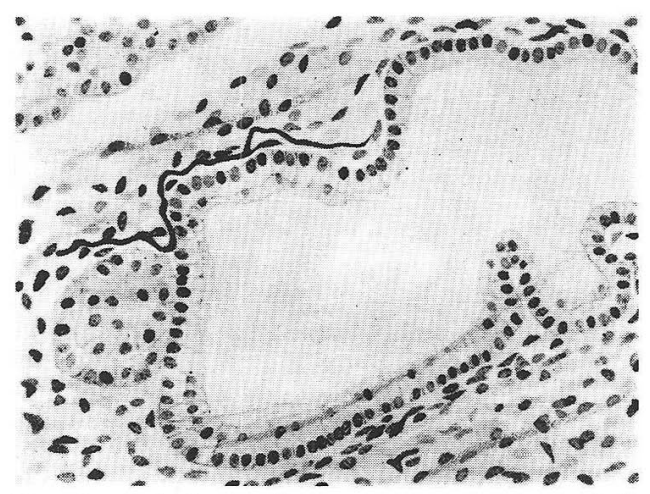

Fig. 4. A bifurcated sensory termination originated in a thick fibre formed around a duct of the COWPER's gland of a bat. Same staining. $\times 200$, reduced to $2 / 3$.

a single thick sensory fibre each coming into contact with the upper and lower surface of the epithelium at a point near the orifice of a duct of a small gland into the urethra, both ending subepithelially in unbranched terminations. In the lower part of the figure, a thin sensory fibre is seen running in company with one of the above thick fibres, to penetrate a little into the urethral epithelium and ending there. 


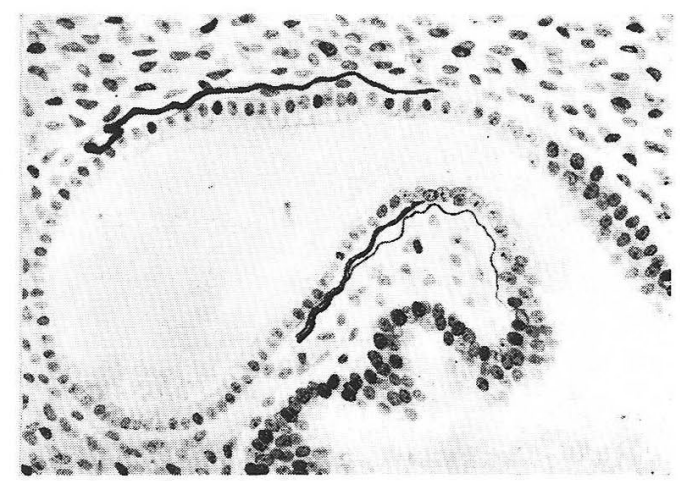

Fig. 5. 2 unbranched thick sensory terminations formed around a glandd duct near its orifice to the urethra and a thin sensory fibre ending in the epithelium of the urethra. Pars diaphragmatica urethrae of a bat. Same staining. $\times 200$, reduced to $2 / 3$.

\section{Summary.}

The sensory fibres coming into the pars diaphragmatica urethrae of bat originate in the small nerve bundles running through the interlobular connective tissue of the powerfully developed COWPFR's glands adjacent to the dorsal side of the urethra and reaching into the urethral propria.

The sensory fibres here are rather smaller in number than those in human and feline urethrae and their terminations are much simpler in form than the latter, corpuscular terminations as found in man and cat being scarcely found in bat. The sensory fibres in bat urethra usually end subepithelially in unbranched and simple branched terminations. Some intraepithelial fibres are also found, but these are very small in number and mostly end in more unbranched terminations.

Frequently, very thick sensory fibres are found running solitary courses around the ducts of the COWPER's glands. These fibres also end subepithelially in unbranched and simple branched terminations in almost all cases, only a very few of them penetrating further into the epithelium.

\section{內 容自 抄.}

蝠蝠尿道横隔膜部に対する知鸴線維は尿道の背部飞直接して強力に発達 する Cowper 氏腺の小葉問結合織内を通って尿道沽有膜に達する小神経束 に由来する。

知覚線維の量は人や猫の場合飞比して可成り劣勢, 又其終末も遥加単 
純に構成される. 即ち小体様終末の如きは殆んど見られず, 知覚線維は専 ら非分岐性及び単純性分岐性終末として上皮下飞終る。其他上皮内線維 も 証明されるが，其数は甚だ少く且つ多くは非分岐性として表わされる.

Cowper 氏腺の導管の周囲に屢々甚だ太い知覚線維の走行を見る．之等 も非分岐性及び単純性分岐性終末となって上皮下に終り，其終末枝が更飞 上皮内に進む事は甚だ稀である。

\section{References.}

Endo: Arch. hist. jap. 6 (1954). - Hori : Tohoku Igaku Zassi. (Jap.). 32 (1943). - Mori : Arch. hist. jap. 8 (1955). - Nobuta: Tohoku Igaku Zassi. (Jap.) 39 (1949). - Sakai : Tohoku Igaku Zassi. (Jap.) 34 (1944). — Seto : Arb. Anat. Inst. Sendai. 22 (1939). 